\title{
The Documentary Record of Nuremberg in the Twenty-First Century
}

Judith Haran

"This is the raw material of history in wonderful profusion."

-Telford Taylor

Few historians would argue that the Nuremberg Trials constitute one of the most significant events of the twentieth century. The trials set the stage for the development of the modern law of warfare, the codification of protocols in the fields of human rights and medical experimentation, and perhaps most importantly, created an indelible, if at times incomplete, record of the crimes of Nazi Germany. In Quincy Wright's summation of the trials' raison d'être in the Harvard Law Review, the third point is of particular interest in this regard:

The Nuremberg trials were designed (1) to carry out the Allied war aim of punishing the major war criminals without denying due process of law to the accused, (2) to influence opinion in Germany and elsewhere in order to deter future aggressions and atrocities, (3) to contribute to the historical record and to public enlightenment by making available authentic evidence of the process of development and methods of the "Nazi Conspiracy," and (4) to contribute to the development of international law, especially on the subjects of war, aggression, and atrocities. ${ }^{1}$

Former Harvard Law School librarian Terry Martin, an early organizer of the Nuremberg Trials Project at Harvard, added this related point: "The documentation from such tribunals helps establish a permanent record of the truth that makes it more difficult for revisionists to try to alter history." ${ }^{2}$ The seventy-fifth anniversary (in 2020) of the trials' commencement offers a welcome opportunity to examine the current status of the evidence.

1 Quincy Wright, "Nuremberg: German Views of the War Trials (review)," Harvard Law Review 69.5 (1956), 964-972, 964, DOI: 10.2307/1337586.

2 "HLS Launches Nuremberg Trials Project," Harvard Law Today, July 31, 2003, https://today.law.harvard.edu/hls-launches-nuremberg-trials-project/. 
The trials were unusual, even precedent setting, in many ways. One of these was the fact that a full three-quarters of the evidence presented was documentary. (An early member of the IMT prosecution staff, Colonel Bill Donovan of the OSS, was said to have departed over this very issue, as he preferred trials based on witness testimony. $)^{3}$

When we think about Nuremberg documents, we tend to think of the familiar Blue, Red and Green Series, the sixty-seven volumes published by the American government around the time of the trials' end. These volumes make up an impressive collection: they take up ten feet of shelf space and weigh some 150 pounds. Despite their size, they contain only a small percentage of the trial records (the Blue Series, Trial of the Major War Criminals Before the International Military Tribunal, reproduces the transcript of the IMT trial, as well as prosecution evidence in original German; the Red Series, Nazi Conspiracy and Aggression, offers 8 volumes of this evidence translated into English; the fifteen-volume Green Series, Trial of War Criminals Before the Nuremberg Military Tribunals under Control Council Law No. 10, offers excerpts of the daily transcripts from the twelve subsequent trials, and selections from the evidence). Robert Kempner, Deputy Chief Counsel of the US prosecution team, stated that the volumes contain less than $10 \%$ of the trial-related documentation. ${ }^{4}$ During the following decade, attention turned to more pressing topics, such as the Cold War, and no further publication of Nuremberg documents was attempted. Fifty years would go by before this situation began to change.

Given the universally acknowledged importance of the thirteen Nuremberg trials, it is surprising how little has been written about their documentary record. A review of the evidence suggests one likely reason: the story of their origin is a confusing one, and the story of where they ended up is only marginally less so.

3 Telford Taylor, "The Use of Captured German and Related Records in the Nuernberg War Crimes Trials," Captured German and Related Records, a National Archives Conference, ed. Robert Wolfe (Athens: Ohio University Press, 1974), 96. This volume is the classic work on the larger topic of captured German records in the United States.

4 Robert Kempner, "The Nuremberg Trials as Sources of Recent German Political and Historical Materials," American Political Science Review 44.2 (1950), 447-459, 449. 
Origins: From Chaos to Order ... more or less

Nuremberg documents are divided into two groups: those generated before and during the war, mostly by the Nazi regime, and captured by Allied troops in 1944-1945, and those generated after the war (interrogation records, affidavits, and records of the court, including transcripts, briefs, motions, etc.) The bulk of the prosecution evidence came from the first group, the files captured at the end of the war.

Captain Lester Born, an archivist working for the Army in 1945, described the chaotic situation of the summer of 1945 in his paper on the Ministerial Collecting Center at Kassel. ${ }^{5}$ (The following description is based on this paper.) During the final year of the war, as Allied troops moved from the periphery of the Reich closer to its center, specialized teams searched for and found many caches of documents in unlikely places, including castles, mines, sawmills, and caves. The records were often in complete disorder, with pages damaged or destroyed by water or fire. (From 1943 onward, German ministries had moved, attempted to destroy, or abandoned huge quantities of records. Orders went out from the top to destroy everything, but most of the caretakers of the files, who had spent years carefully curating them, resisted these orders.) US and British forces set up document collecting centers throughout Germany, and enormous quantities of material began to pour in immediately.

The document center at Kassel was only open for half a year, but within the first three months, the hastily repaired complex of buildings became home to some 1200 tons of documents and 52 tons of microfilm. This was a true bootstrap operation. The officers in charge had to clear out and repair buildings, get rid of significant quantities of explosives and hazardous chemicals, and even reopen a local sawmill to provide shelving, so that the contents of all those boxes would be accessible.

Accessibility was high on the agenda, because so many people needed these files. There was no functioning government left in Germany in the summer of 1945, no remnant of intact bureaucracy that the Allies could administer. It all had to be recreated. Many of the visitors to the document centers were seeking records that would help them in this gargantuan task. The staff of this one document center alone contained hundreds of Germans who had been employed in various Nazi ministries. They provided invaluable assistance in sorting, cataloguing, and classifying the avalanche

5 Lester Born, “The Ministerial Collecting Center near Kassel, Germany," American Archivist 13.3 (1950), 237-258. 
of paper, as well as preparing thousands of cataloguing cards, accession lists, and the critical lists of what had been received, shipped, and reproduced. In addition to hauling heavy crates from trucks into buildings, they made photostats of whatever was requested by visitors, and once even spread index cards out to dry on the grass after a flood. Born notes that almost all of the shipments arrived unannounced; one day a 70,000 volume library from the Foreign Office turned up, in complete disarray; another day saw the arrival of the complete files of the Polish Weather Bureau.

The operation at Kassel was only a small part of the whole. Documents related to industry (business and correspondence records of the Farben, Flick, and Krupp industrial empires) were collected at Fechenheim, outside of Frankfurt. Naval documents, including most of the history of the German navy, ended up in Tambach castle, fifty miles north of Nuremberg, far from the sea. Thousands more tons of German documents found their way to the Berlin Document Center. Records of the German High Command, Party records, and more were packed into crates and footlockers for the long journey across the Atlantic to the Pentagon. And even now we still do not know how much of the record of the Third Reich was taken by the Soviets. For when it came to documents (and other treasures, such as gold, currency and artwork) there was no Four-Power agreement. Whoever got there first took whatever they found.

Visitors to the document centers included officials from countries that had been occupied by Germany, members of various military and intelligence staffs, as well as the many officials of OMGUS, the Office of Military Government, United States, that had been charged with no less a task than administering civil society after cessation of hostilities. Prosecution staff from Nuremberg also made up a significant percentage of the visitors. Day after day they sifted through the chaotic assemblage of files, looking for evidence of war crimes and crimes against humanity. Fortunately, such evidence was not hard to find; the Nazi regime had kept meticulous records of everything. Among their finds was the sole surviving copy of the Wannsee Protocol and the only known surviving set of official reports on the activities of the Einsatzgruppen in the Soviet Union (these reports, about the activity of the SS execution squads in the Soviet Union, was to form the basis of the ninth of the Subsequent Trials, the Einsatzgruppen Trial).

At the beginning, control over the captured documents was incomplete. Many original documents disappeared and were never seen again. Eventually, administrators insisted that investigators from Nuremberg take only photostats, not originals. Even so, many of these documents had been 
ripped out of their original contexts, sometimes literally, creating a nightmare for post-1949 archivists and historians.

Investigators didn't limit themselves to these document centers, however. Scouting teams from Nuremberg went on missions as far afield as Poland, Czechoslovakia, Holland, even Norway. The library at headquarters of I.G. Farben was a rich source of material. OCCWC (Office of Chief of Counsel for War Crimes) had offices in Berlin, Frankfurt, Paris, and Washington, with analysts (and shipping teams) in all of these. With documents coming in from all of these sources, those left behind at the Palace of Justice had to scramble to make arrangements for housing all of this paper.

\section{From Documents to Convictions}

Several authors have referred to the Document Room at Nuremberg as the most important location after the courtrooms themselves, or even as the "hub of the trial." Shelves filled the room from floor to ceiling, necessitating the frequent use of ladders. John Mendelsohn, author of Trial by Document, found so few records about the document operation that he had to rely on interviews to understand how it worked. Many more documents arrived than were eventually used. Faced with stacks of collected material, and with more arriving hourly, lawyers and analysts had to choose those items with the greatest promise of incriminating the defendants.

The man in charge of the Document Division for the IMT, Major William H. Coogan, certified authenticity for whatever the prosecution presented in court. For the later Nuremberg Military Tribunal (NMT, in charge of the subsequent trials), his counterpart was civilian Fred Niebergall, Chief of the Document Control Branch, OCCWC. Niebergall was responsible for safeguarding, duplicating, and arranging for translation of everything. The Language Division, in its peak year of operation (19471948), translated and stenciled 133,762 pages. ${ }^{6}$

After selection, the next step was classification. Document Room staff sorted many documents by general subject (i.e. "NG for Nazi Government"), but a significant number of items, especially for the IMT, were

6 John Mendelsohn, Trial by Document: The Use of Seized Records in the U.S. Proceedings at Nuernberg (Ann Arbor, Michigan: University Microfilms, 1975), 26. (Considered to be an essential reference for anyone dealing with the documentary record of Nuremberg.). 
sorted by provenance/source. Ten series were established for the IMT; the subsequent trials generated six more. A list of major groups follows:

IMT series:
C Crimes
D Industry
EC Economics
ECH Economics-Heidelberg
ECR Economics-Reichskreditkassen
L London
M Melvin (Melvin Jones, Assistant Prosecutor, UK)
PS Paris-Storey (Col. Storey, the principal document collector for IMT)
R Rothschild (Lt. Rothschild in London)
TC Treaty Committee

NMT series:

NOKW Nuremberg High Command (Oberkommando der Wehrmacht)

NO Nuremberg Organizations

NI Nuremberg Industrialist (includes subseries NID and NIK)

NG Nuremberg government (ministries)

NM Nuremberg miscellaneous (mostly labor related)

NP Nazi Party abroad (Auslandsorganisation)

After documents had been given a series identity/prefix, ten photostat copies were made, a stencil was cut, and 100 mimeographed copies were produced. After this came translation (into English, French, and Russian for the IMT, but subsequently only into English and German for the NMT trials) and then description. This occurred via two methods: register cards and Staff Evidence Analyses (SEAs). Register cards included basics such as title, date, provenance, language, original document ID, Nuremberg document number, persons/organizations implicated; the SEAs also included a summary, an explanatory note, and a list of subject headings. Usefulness of the SEAs varied widely according to the ability of the analyst to comprehend the subject matter (and to read German accurately). Analysis, far from being a leisurely pursuit, was performed under a lot of time pressure. 
After analysis, documents went through final selection by prosecution teams and were assembled into "document books" by topic. Most books had a comprehensive index at the beginning, sometimes running to several pages. Many documents, referred to as "loose documents," never made it into these books; this was particularly true of items introduced during cross-examinations. A lot of potential evidence wasn't chosen for the document books to start with, and not everything in those books was presented or accepted as evidence in the court room.

Although figures vary by source, noted archivist Fritz Epstein stated that for all of the trials, a total of over 750,000 mimeographed pages were produced. ${ }^{7}$ This included a total of 330,000 pages of transcripts alone, of which only the IMT transcript was published.

\section{Finding Homes for 100 Tons of Records}

On April 13, 1949, the Ministries Trial, the last and longest of the judicial proceedings, reached an end. The Publications Team had been hard at work for some time already, deciding which documents and trial excerpts to include in the forthcoming government volumes. Now it was time for the vast, complicated machinery, set up nearly four years before, to be taken apart. The written record of the trials had to be addressed with an eye to the future. The immense task of dealing with the residual documents (over one hundred tons, according to John Mendelsohn) ${ }^{8}$ fell to the Chief of the Document Division, Fred Niebergall.

In his Final Report to the Secretary of the Army on the Nuernberg War Crimes Trials, Taylor, the Chief of Counsel for the twelve subsequent Nuremberg trials, describes the process. He makes it clear that "one of the most important problems connected with the deactivation of the military tribunals was the disposition of the very large amount of documents ... assembled in connection with the trials." 9 After noting that the complete original record was to be deposited at the National Archives, he goes on to

7 Fritz Epstein, "Washington Research Opportunities in the Period of World War II,” American Archivist 17.3 (1954), 225-236, 235.

8 Mendelsohn, Trial by Document, 128.

9 Telford Taylor. "Final Report to the Secretary of the Army on the Nuernberg War Crimes Trials under Control Council Law No. 10," Washington, DC: U.S. Government Printing Office, 1949, 98, https:/www.loc.gov/rr/frd/Military_Law/pdf/NT_fi nal-report.pdf. 
list the repositories to which a "fairly complet" set of records was being donated:

- Library of Congress

- Harvard Law School Library

- Nuernberg State Archives (while the trials were still in progress, a representative of this archive had been hard at work on site, securing documents)

- One set donated to each of the nations that maintained a permanent delegation at Nuremberg: England, France, Holland, Czechoslovakia, and Poland (USSR is not mentioned in this list)

Taylor then goes on to list the destinations of the less complete sets (consisting of court transcripts, prosecution documents, and staff evidence analyses only):

- University of California

- University of Chicago

- Columbia Law School

- Duke University

- Hoover Institute (Stanford University)

- New York Public Library

- University of North Dakota

- Northwestern University

- Princeton

- University of Michigan

- University of Washington Law School

- U.S. Military Academy at West Point

- University of Washington

- Wiener Library, London

- United Nations at Lake Success, NY (temporary headquarters until 1952)

The following German universities were also listed as recipients of trial records: Bonn, Heidelberg, Frankfurt, Goettingen; other sets were donated to the Bayerische Staatskanzlei in Munich, the Swiss Social Archives in Zurich, Yad Vashem, and Berlin's Kaiser Wilhelm Institute (current status of non-US collections has not been investigated).

Later sources, including an official OMGUS press release, named additional US repositories as recipients of these records. Four such lists exist, and none of them agree. Together, these lists name twenty-eight US libraries and/or archives. Nearly seven decades later, only twelve of these institutions were able to confirm the existence of trial records in their collec- 
tions. Appendix A provides a list of these, with current status of records (reported or discovered as of 2018).

Since the records' arrival in the US, very little has been written about the documents themselves (as opposed to the content of the documents). Only four articles on this topic have ever been published in English: two by members of the prosecution team, one by the head of the Document Division, and one by a Library of Congress archivist-all prior to 1955 . Chief of Counsel Telford Taylor wrote about research possibilities afforded by the trial record ${ }^{10}$ before the final trial had concluded; a year later Deputy Chief of Counsel Robert Kempner summed up the situation in The American Political Science Review. ${ }^{11}$ Fred Niebergall, head of the Document Division, described the records' current status for the Law Library Journal. ${ }^{12} \mathrm{~A}$ few years later, Library of Congress archivist Fritz Epstein wrote about "research opportunities in Washington, DC for the WWII period." 13

The situation is not much different with regard to books. Of the three relevant titles that appeared by the mid-seventies, two were written by NARA archivist John Mendelsohn: his PhD thesis ${ }^{14}$ analyzing the four main document series used in the twelve "subsequent" Nuremberg Military Tribunal trials, still considered a primary source for anyone dealing with these documents, and his detailed finding aid to the microfilmed NARA documentary record for NMT Case 9, the "Einsatzgruppen Trial." 15 In 1976, Jacob Robinson, a legal scholar, and Henry Sachs, a former document analyst at Nuremberg, compiled a detailed, well-indexed list of 3001 Nuremberg documents (listed by evidence file number, and heavily annotated) pertinent to the Holocaust. ${ }^{16}$ One other useful catalogue is the 1961

10 Telford Taylor, "Forum Juridicum: An Outline of the Research and Publication Possibilities of the War Crimes Trials," Louisiana Law Review 9.4 (1949), 496-508, available at: http://digitalcommons.law.lsu.edu/lalrev/vol9/iss4/4.

11 Kempner, "The Nuremberg Trials."

12 Fred Niebergall, "Brief Survey Concerning the Records of the War Crime Trials Held in Nurnberg, Germany," Law Library Journal 42 (1949), 87-90.

13 Epstein, "Washington Research Opportunities."

14 Mendelsohn, Trial by Document.

15 John Mendelsohn, War Crimes Trials: Records of Case 9 (Washington, DC: National Archives and Records Administration, 1978).

16 Jacob Robinson and Henry Sachs, The Holocaust: The Nuremberg Evidence, Part One (Jerusalem, Israel: Yad Vashem, 1976). (An extremely useful, exhaustive compendium of evidence relating to the Holocaust: 3001 documents are described, and each listing notes whether the document has appeared in other publications. 
Catalogue of Nuremberg Documents ${ }^{17}$ from London's Wiener Library, which not only lists prosecution and defense documents, but also references a separate list of 4500 interrogation summaries. An additional catalogue of Nuremberg-related materials is the useful European War Crimes Trials: a Bibliography, ${ }^{18}$ published by the Carnegie Endowment for International Peace. This well-annotated list of books and articles is unfortunately limited by its temporal coverage (1941-1950) as well as a lack of later editions.

The most recent discussion of the documentary record is another essay by Telford Taylor, "The Use of Captured German and Related Records in the Nuernberg War Crimes Trials," 19 found in the classic 1974 anthology, Captured German and Related Records, a National Archives Conference. Although the trial record has contributed to countless works of historical and legal analysis since 1949, no further works in English discussing the documents themselves have emerged. ${ }^{20}$

After all this time, some might argue that this lack of discourse on the trial documents no longer matters. Access to trial records remains a challenge; fewer than half of the record sets described in 1949 can now be located. Apart from the complete trial record held at NARA, a significant set of Nuremberg trial records can be found at only a handful of the listed institutions. ${ }^{21}$ Telford Taylor's statement that "the most immediate problem

Names, places, subjects, institutions, and areas are indexed (index is half of the book).).

17 Wiener Library, Catalogue of Nuremberg Documents (London, Wiener Library, 1961). (Mimeographed list of their holdings, organized into prosecution documents, defense documents, and a sixty-page list of testimonies with relevant trial transcript pages noted.).

18 Inge Neumann, European War Crimes Trials: A Bibliography (New York: Carnegie Endowment for International Peace, 1951). (Intended for scholarly use in the field of international law, this detailed bibliography includes publications in several languages between 1941 and 1950 . Roughly 2/3 of the citations are annotated.).

19 Taylor, "Captured Records."

20 An amusing exception to this was the flurry of news articles, mostly from 2013, on the controversy between the US Holocaust Memorial Museum and the heirs of Deputy Chief of Counsel Robert Kempner, who had shipped eight tons of documents from Nuremberg to his home in Pennsylvania in 1949 (see Robert Wittman and David Kinney, The Devil's Diary: Alfred Rosenberg and the Stolen Secrets of the Third Reich (New York: Harper, 2016).

21 See Appendix A for complete list. Note also that many repositories in addition to those named have collections of personal papers of trial participants: Cornell's 
is that those records be disposed of in such a way that they will be available to those who need them,"22 remains as true today as it was in 1949.

\section{Uses of the Trials' Record}

Various authors have described how these records have been used over the years, beyond the most obvious application-historical research. Mendelsohn states that prosecutors in Germany used them to convict many war criminals after $1950 .{ }^{23}$ In West Germany alone, more than 70,000 people were tried for war crimes by the end of 1968, with over 6,000 convictions. By 1965, 13,000 people had been convicted of war crimes in East Germany, including personnel of Sachsenhausen concentration camp. The records were frequently consulted during the writing of memoirs by judges (Musmanno), defense attorneys (Kranzbuehler, Haensel), prosecution attorneys (Taylor, Harris, Kempner), defendants (von Knieriem, Speer) and even translators (Sonnenfeldt). Telford Taylor is not the only writer to issue a caution about the use of these records, pointing out that documents were selected for the purposes of proving the guilt of German defendants, not with an eye towards the historical record. In addition to content concerns, not-infrequent errors in translation continue to cause headaches for researchers, just as they did for defense counsel during the trials.

One less obvious use of evidence files was in the search for missing persons after the war. Several affiants in Trial 8, for example, testified to the kidnapping of children in the East, often giving names. Documents captured from the files of Lebensborn and the Volksdeutsche Mittelstelle frequently contain long lists of names of adults and children living in resettlement camps after being expelled from their native land.

\section{Trial Records in the Modern Era: The Case of Harvard Law School}

Apart from the National Archives, Harvard is the only US institution currently thought to have a nearly complete set of trial records. In 1949, they received approximately one million pages (i.e., between seven and twelve

Donovan collection and the Robert Jackson papers at the Library of Congress are only two examples. See Appendix B for list of these.

22 Taylor, "Forum Juridicum," 508, emphasis added.

23 Mendelsohn, Trial by Document, 163-164. 
tons of paper). In the 1990s, Law School librarians realized that this enormous, aging collection would need significant attention to ensure its survival for use by future researchers.

Over the first fifty years of their existence, the trial records had been stored haphazardly wherever space could be found: unused stairwells, filing cabinets in damp cellars. Some boxes sustained water damage as a result. Preservation of the collection became ever more urgent due to the fragile condition of the paper. Library staff opted for digital preservation, with the eventual goal of access to the entire record of the trials in English via a permanent website.

The HLS collection contains transcripts for each of the trials, including indictments, arraignments, opening and closing statements, judgments, and sentencing, as well as trial briefs, all prosecution and defense exhibits (referred to as case files); plus the much larger set of source documents from which most prosecution trial exhibits were selected. These so-called "evidence files," a full sixty percent of the HLS collection, contain not only captured Nazi documents, but also affidavits, interrogations, articles from newspapers, and excerpts from Nazi law journals.

750,000 pages from the collection were selected for digitization, an enormous undertaking that would end up taking far more time and resources than anticipated. (The remaining 250,000 pages were duplicates, or were in German.) As digitization progressed, the paper originals were transferred to the Harvard Depository, an enormous high-density book and media storage facility located in a remote forest in Southborough, MA, thirty miles west of the Law School.

\section{The Collection: Making All of this Paper Accessible}

Before the arrival of the Internet, a collection as large and unwieldy as the million-plus pages of Harvard's Nuremberg records presented library and archive staff with a serious question: how to arrange these papers and make them fully accessible to users? The fact that so few of the US repositories owning these records (other than NARA) appear to have created a finding aid in the fifty years since their original distribution speaks to this challenge. ${ }^{24}$

24 NARA archivists compiled three finding aids between 1949 and 1966. The first one, Preliminary Inventory No. 21, was digitized by Google and put online by HathiTrust. Aside from the official, published records of the Trials contained in 
Harvard Library staff decided early on that this challenge required a new tool, something far deeper and richer than a traditional $20^{\text {th }}$ century finding aid. The ambitious objective of full-text and document-level discovery mandated the use of a website, supported by a sophisticated database capable of holding all data fields relevant to users. The website's user interface also features rich orientation materials:

- for each trial:

- a basic narrative

- an indictment, with specific counts

- list of trial issues (e.g., hostage taking, medical experiments)

- a detailed chronology, with dates matched to transcript pages

- lists of defendants, counsel for both sides, judges, witnesses

- explanatory material (charts, list of evidence file groups, etc)

- a "Who Was Who" in Nazi Germany

- an explanation of how trial documents are organized, structured, and analyzed

- a choice of basic or advanced fielded search for documents (for NMT trials 1-4 and 7 so far) and document images

- keyword search for trial transcripts (for NMT trials 1-4 and 7 so far)

- a collection of trial-related photographs

- a history and description of the project

As of this writing, the Nuremberg Trials Project website has 55,285 pages analyzed, uploaded and ready for inspection. These include the trial-related "case files" for Cases 1-4 and 7, plus "evidence files" - other documents relevant to Cases 1 and 2, and a partial set for Case 4. These documents are interlinked and fully searchable at http://nuremberg.law.harvard.edu.

With this many documents (and many more to come), design of the search function for documents and transcripts is critical. A number of search options exist. Within any given trial, one can filter transcript search results by date (a drop-down menu lists all dates that trial was in session), author, defendant, or trial issue. For example, for Case One, the Medical Case, clicking on "Karl Gebhardt," one of the twenty-three defendants, returns sixty-nine results. Clicking on the title of any of the listed documents brings up an image of the paper document. (A magnification option is available.)

the Blue, Red, and Green sets, it remains the only known online guide to the Nuremberg records in English. The two later NARA finding aids are available only at NARA and at the Wisconsin Historical Society. 
In this example, clicking on the first title in the list brings up an image of a 1946 affidavit by Oswald Pohl about medical experiments on concentration camp inmates. The document has an original Nuremberg evidence code of NO-65. The information panel to the right of the image provides links to the author and to the defendants mentioned. Clicking on the evidence code number, NO-65, brings one to a list of all forms of this document: a photostat of the German original, a German transcript of it, an English translation of it, and its Staff Evidence Analysis. All of these images can be downloaded as PDF files.

An advanced search option is found at the bottom of the home page. The page gives a high-level overview of all 10,000 individual documents currently available; users can narrow a search by material type, date, trial, defendant, author (101 so far), language, source, or trial issue. It is perhaps this latter choice that researchers will find most useful: 80 issues are listed so far, ranging from "hostage-taking and reprisal actions" to "sterilization experiments." (Trial issues are taken from a controlled list, as are names for case files.)

The ability to search through this immense trove of records and quickly pull out all documents related to a specific issue, such as "Night and Fog Decree," is an example of the power of digitization. Having the trial record online opens up new research possibilities. The user can instantly access 86 documents relevant to this issue; a search of the best alternative site (Library of Congress Military Legal Resources) brings up nothing.

\section{A Look at Other Online Collections}

Only a few digital libraries have trial-related records - Cornell's Donovan Collection, Yale's Avalon Project, the Library of Congress, the University of North Dakota:

- Cornell's Donovan/Nuremberg Trials Collection offers nearly 2000 digitized documents online, selected from a larger collection of over 150 volumes of trial-related materials, as well as personal papers of Col. Donovan.

- The Avalon Project offers a complete online transcript of the International Military Tribunal at Nuremberg (the first, most famous trial) but without actual page images, evidence files, or links to cited documents. (The transcript is a copy of that found in the "Blue" series.) Many ancillary documents, as well as key documents from Trial 4, are also found on this site. There is no coverage of the other NMT trials. 
- The LoC site offers searchable PDF versions of the original Blue, Green and Red series of volumes issued by the US government at the conclusion of the trials.

- The University of North Dakota has digitized 1100 pages (of their 240,000 page collection) related to the German invasion and occupation of Norway, in a project funded by the Museum of the Norwegian Resistance in Oslo.

The National Archives and Records Administration owns the complete record of the trials in both paper and microfilm. A few items are available online, but viewing the actual record requires visiting Washington or purchasing costly microfilm. (To purchase the 48-roll microfilm record of Trial 7 , as an example, at $\$ 125 /$ roll, would cost $\$ 6000$.)

Supplementing the official record, of course, are the many collections of personal papers of trial participants; 27 of these (from 24 men $^{25}$-judges, prosecutors, an economic analyst, and a psychiatrist) are listed in Appendix B. Similar collections are likely to be found in German archives. Ten of these collections are partially digitized, and offer a fascinating selection of private notes, newspaper clippings, trial documents, photographs, and ephemera.

Of these, the most fully accessible is the collection at Harvard of Assistant Counsel Drexel Sprecher's papers. Each of the more than 22,000 pages has been digitized, with a direct link embedded into the container list of the finding aid. Other collections, such as Thomas Dodd's papers at the University of Connecticut, with over fifteen hundred digitized items, are also worth perusing. (See Appendix B for a complete list of these collections.)

\section{Linked Repositories: Still in the Future}

In three of the cases mentioned above, a donor's personal papers are split between two repositories. Not one of these six websites informs the user of this fact. Even the Robert Houghton Jackson Center, a stand-alone nonprofit and archive devoted to the life and work of the former Supreme

25 At least six women were members of the US prosecution team. See Diane Marie Amann, "Portraits of Women at Nuremberg" (2010), available at: http://digitalco mmons.law.uga.edu/fac_artchop/1004, for details. One woman also served on the French prosecution team at the IMT. See also http://www.intlawgrrls.com/2007/0 6/women-at-nuremberg-prosecutors.html. 
Court justice, does not mention that some of Jackson's papers are held at the Library of Congress. None of the repositories refers the reader to related collections held elsewhere. (Each trial had multiple judges and prosecutors, so links to the relevant archives would be of great help to those researching any given trial.) As it stands now, only through use of a search engine can one get a complete picture of archival holdings related to Nuremberg. (Moreover, it is entirely possible that other collections of relevant personal papers exist in the United States, collections with no online presence at all.)

All of this leads one to wonder: wouldn't it be useful for repositories to become more aware of outside resources that are related to their own holdings? Providing linkage to related collections would be a great boon to future researchers, would save everyone a lot of time, would cost nothing, and would reflect well on each participating archive. Isn't it about time we got out of our silos and started cooperating?

\section{Is the Future of Research Online?}

The Nuremberg Trial Project website was launched in 2003. Since that time, the site has steadily attracted several hundred visitors per day. Several thousand websites (in over twenty languages) have linked to the Harvard site. According to Google Scholar, over a hundred scholarly articles and hundreds of books have cited the project website since its launch. As more material is uploaded, the number of visitors will continue to grow.

It will be a few more years before the entire record of the trials is online. It's possible that this milestone might be achieved in time for the 75th anniversary of the beginning of the Trials. The next phase of the projectstill on the drawing board today-could include linkage out to related collections around the world, as well as to entities such as DBpedia, "a crowdsourced community effort to extract structured information from Wikipedia and make this information available on the Web." 26 In addition, API delivery of document metadata (i.e., delivery to machines by means of an "application programming interface") is anticipated. With these features and others still under discussion (or awaiting discovery), it appears certain that the Nuremberg Trials Project will become the leading resource in this field ... and it will make life much easier for those wishing to examine this fascinating episode of twentieth-century history. 


\section{APPENDIX A}

U.S. "recipients" of trial records in 1949, with current status (paper unless otherwise noted*)

National Archives and Records Administration: complete paper and microfilm record

Harvard Law School: one million pages of trial records (all 13 trials, partly digitized)

University of Washington School of Law: 1,236 bound volumes (all 13 trials)

Center for Research Libraries, Chicago: extensive holdings (all 13 trials)

University of North Dakota: 240,000 pages total; 1100 documents related to occupation of Norway digitized (https://library.und.edu/digital/nuremberg-transcript $\mathrm{s} /$ )

University of Michigan: 413 volumes covering Trials 1-12 (and possibly IMT)

University of Cincinnati: fifty volumes, IMT transcript plus index

Hoover Institution/Stanford University: 75 linear feet, IMT only

Columbia University: extensive holdings (all 13 trials)

University of Georgia Law School: Several indictments, opening/closing statements, and judgments, plus dissenting opinions, motions, and transcripts of a few videos. Trial 11, the "Ministries Trial," is exceptionally well documented.

http://digitalcommons.law.uga.edu/nuremberg/

University of Southern California: 300 boxes of transcripts of all 13 trials (this repository was not mentioned in any contemporaneous source as a recipient)

National Library of Medicine, NIH (formerly Army Medical Library): 18 linear feet of transcript and evidence from Medical Trial

Correspondence (end of 2017) with the following "named recipients" revealed no significant collections of trial documents. $*$ indicates collection of personal papers-see Appendix B.

$\begin{array}{lll}\text { University California-Berkeley } & \text { University of Chicago } & \text { Duke } \\ \text { Princeton } & \text { Northwestern } & \text { West Point } \\ \text { University of Wisconsin } & \text { University of Arkansas } & \text { Georgetown } \\ \text { University of Nebraska } & \text { NY Public Library } & \text { Cornell }^{* *}\end{array}$

University of Texas ${ }^{* *}$

"Most academic libraries own the official published volumes of trial records, referred to as the "Blue," "Red," and "Green" series. The above list refers to the actual trial records only (bound or unbound), and not to these published multivolume series. 


\section{APPENDIX B}

Principal U.S. Collections of Personal Papers related to the Trials (alphabetical by donor surname)

Nürnberg Krupp Trial Papers of $\mathrm{Hu}$ C. Anderson, Vanderbilt University, Nashville, TN: https://krupp.library.vanderbilt.edu

Walter Beals Papers at University of Washington, Seattle, WA: http://archiveswest.o rbiscascade.org/ark:/80444/xv47470

Francis Biddle Papers at Georgetown University, Washington, DC: https://repositor y.library.georgetown.edu/handle/10822/559026

and the Francis Biddle Collection at University of Syracuse, Syracuse NY: https://li brary.syr.edu/digital/guides/b/biddle_f.htm

Guide to Trial Notebooks from Nuremberg Justice Case at University of Texas, Austin TX: Judge Mallory Blair collection, includes 70 volumes of records from this trial: https://legacy.lib.utexas.edu/taro/utlaw/00022/law-00022.html

Edward F. Carter Papers, Nebraska Historical Society, Lincoln, NE: https://history. nebraska.gov/collections/edward-francis-carter-1897-1981-rg4231am

William Christianson Papers at U.S. Holocaust Memorial Museum, Washington DC: https://collections.ushmm.org/search/catalog/irn502047

Richard Dillard Dixon Papers, East Carolina University, Greenville, NC: https://dig ital.lib.ecu.edu/special/ead/findingaids/0601/

and University of N. Carolina, Chapel Hill, NC: http://finding-aids.lib.unc.edu/035 671

Thomas Dodd Papers at University of Connecticut, Storrs, CT: http://archives.lib.u conn.edu/islandora/object/20002\%3A20

Donovan Nuremberg Trials Collection at Cornell University, Ithaca, NY: http://la wcollections.library.cornell.edu/nuremberg

Benjamin Ferencz Papers at U.S. Holocaust Memorial Museum, Washington DC: https://collections.ushmm.org/search/catalog/irn508277

Paul H Gantt Nuremberg Trial Papers at Towson University, Towson, MD: http://li brary.towson.edu/digital/collection/gantt

Winfield B. Hale Papers at University of Tennessee, Knoxville, TN: http://dlc.lib.ut $\mathrm{k} . e d u / s p c / v i e w ? d$ ocId=ead/0012_002411_000000_0000/0012_002411_000000_00 00.xml

Hebert Nuremberg Collection at Louisiana State University, Baton Rouge, LA: https://digitalcommons.law.lsu.edu/nuremberg/

Robert H. Jackson Papers at Library of Congress, Washington, DC: https://www.lo c.gov/item/mm83061408/

and the Robert H. Jackson Center Archive, Jamestown, NY: https:/www.roberthja ckson.org/archive/ 
Robert Kempner Papers at U.S. Holocaust Memorial Museum, Washington DC: https://collections.ushmm.org/search/catalog/irn502566

Douglas McGlashan Kelley Papers at University of California, Santa Cruz, CA: http://www.oac.cdlib.org/findaid/ark:/13030/kt5d5nc7tj/entire_text/

Michael A. Musmanno Papers at Duquesne University, Pittsburgh, PA: http://guide s.library.duq.edu/musmanno-nuremberg

John Johnston Parker Papers at University of North Carolina, Chapel Hill, NC: http://finding-aids.lib.unc.edu/03566/

Henry Schneider Papers at Columbia University, NY, NY: https://findingaids.librar y.columbia.edu/ead/nnc-rb/ldpd_10392013/

Harold Sebring Papers at Stetson University, DeLand, FL: http://digital.archives.ste tson.edu/cdm/search/collection/LawSebring/order/descri

Drexel Sprecher Collection at JFK Presidential Library, Boston, MA: https://www.jf klibrary.org/Asset-Viewer/Archives/DASPP.aspx

and the Sprecher Collection at Harvard Law School Library, Cambridge, MA: http://oasis.lib.harvard.edu/oasis/deliver/ law00216

Telford Taylor Papers at Columbia University, New York, NY: http://www.columb ia.edu/cu/lweb/archival/collections/ldpd_10199444/

Charles Wennerstrum Papers, Drake University Law School, Des Moines, IA: http:/ /www.drake.edu/law/library/collections/special-collections/

John C. Young Papers at the Truman Library, Independence, MO (in which Case 12, the High Command Trial, is particularly well documented): https://www.tru manlibrary.org/hstpaper/youngjc.htm

Harry S. Truman Presidential Library and Museum hosts the "War Crimes Trials at Nuremberg" Collection. This wide-ranging collection features 335 documents totaling 4146 pages, plus photographs, oral history transcripts, and more: https:/ /www.trumanlibrary.org/whistlestop/study_collections/nuremberg/index.php?ac tion $=\mathrm{bg}$ 
